\title{
Relationship between Operative Time and Complications for Impacted Mandibular Third Molar Removal
}

\author{
Paras Rahim Baloch, Suneel Kumar Punjabi, Shuja Hamid, Priya
}

\begin{abstract}
OBJECTIVE: To identify relationship between operative time and surgical complications encountered during and soon after removal of impacted $3^{\text {rd }}$ Molar teeth.

METHODOLOGY: This cross-sectional study was conducted at the department of Oral \& Maxillofacial Surgery, Faculty of Dentistry, Liaquat University of Medical \& Health Sciences, Jamshoro from February 2017 to July 2017. Total ninety two surgical removals were done after pre-operative assessment of impaction. Operative time was recorded. Any intra-operative complication was noted during surgery and postoperative complications were recorded on $3^{\text {rd }}, 5^{\text {th }}$ and $7^{\text {th }}$ day. The Data was analysed by statistical software package SPSS version 20.0 Qualitative variables were expressed as absolute frequencies and percentages. The variables were presented as mean, frequencies/percentages.

RESULTS: The results of this study showed that surgical removal of third molar was more common in females $(58 \%)$ with the highest percent of mesioangular $(39 \%)$. The pre-operative pain was more in females and older patients. In intraoperative complication, injury to soft tissue was more common than other complications. In postoperative complications, swelling and trismus were more on the $3^{\text {rd }}$ day.

CONCLUSION: The inflammatory complications that can be considered (pain, swelling and trismus) after third molar surgery remain an important factor at the early postoperative periods. The intraoperative and postoperative complication also depends on surgeons experience and duration of procedure which may increase or decrease the sequela of removal impacted teeth.
\end{abstract}

KEY WORDS: Operative Time, Impaction, Impacted mandibular, Third molar.

This article may be cited as: Baloch PR, Punjabi SK, Hamid S, Priya. Relationship between Operative Time and Complications for Impacted Mandibular Third Molar Removal. J Liaquat Uni Med Health Sci. 2019;18(03):219-24. doi: 10.22442/jlumhs.191830631

\section{INTRODUCTION}

Teeth that are unable to erupt in an expected time in the dental arch are known as impacted or a tooth which is placed against soft tissues or hard tissue (bone) or both and its unlikely to erupt further in the dental arch is called impacted tooth ${ }^{1}$. Generally, the eruption time of this tooth is between 17 to 21 years ${ }^{2}$. A tooth may become impacted but the most common and the highest impaction rate is of mandibular third molar followed by maxillary $3^{\text {rd }}$ molar, maxillary canine and mandibular premolar $^{3,4}$. Lower third molar is the last tooth which erupts between the age of 17 to 25 years and most of the times maligned, with curved or hooked roots all this happen due to lack of space between mandibular ramus and second molar ${ }^{2}$.

The problems which can occur due to impaction are pericoronitis the most common followed by dental caries of third molar or adjacent second molar, root resorption of the second molar, periodontal problems, odontogenic cysts and tumors, other factors that need considered is bad oral hygiene ${ }^{5,6}$.
Mandibular third molar surgery is the most common surgical procedure performed after simple extraction in the outdoor patients ${ }^{7,8}$. During surgical removal of impacted lower $3^{\text {rd }}$ molar intra-operative accidents and postoperative complications are not uncommon. The intra-operative complications can occur like profuse bleeding, injury to inferior dental canal, injury to adjacent tooth, displacement of tooth in the adjacent structure, fracture of the root apex, fracture of mandible and jaw dislocation ${ }^{9,10}$.

Type of impaction, existing infection (pericoronitis), relationship with the inferior alveolar nerve, root morphology, density of the bone surrounding the impaction or any pathology associated with impaction are the tooth related factors which may cause the postoperative complications ${ }^{11}$.

The factors involving surgery are the use of drugs i-e local anaesthesia, type of extent of the incision, bone removal or tooth sectioning, the technique of closure of the wound, surgeons experience and time spent during the surgery ${ }^{12,13}$. The bone density also needs attention, difficulty level of impaction ${ }^{14}$. 
The postoperative complications are divided into immediate tissue reaction and delayed complications. Immediate complications which occur on the first day following surgery include pain, trismus, swelling, dysphagia ${ }^{15-18}$ while delayed complications include bleeding, dry socket, wound dehiscence, delayed wound healing, infections, periodontal pocketing of adjacent tooth and nerve injury ${ }^{2}$. In addition, other rare complications such as fracture and jaw dislocation also have been reported ${ }^{19,20}$.

This study was aimed to determine the effect of operative time on immediate post-surgical tissue reactions following lower third molar surgery which are common and also patient's primary concern and to reduce, prevent such complications in future.

\section{METHODOLOGY}

Total ninety two patients were enrolled in this study by the approval of ethical review committee of Liaquat University of Medical and Health Sciences Jamshoro with reference No/ LUMHS/ERC 575 dated 27-012017. This clinical cross-section descriptive, prospective trial was done at department of Oral \& Maxillofacial Surgery, Faculty of Dentistry, Liaquat University of Medical \& Health Sciences, Jamshoro from February 2017 to July 2017. The patients included of both the genders with the sample technique of simple randomization method, patient's age range from 18 to 35 years and patients having impacted clinically \& radio-graphically proven mandibular third molar. Patients not willing to participate in the study, signs of infection (acute pericoronitis), smoker patient, patient on oral contraceptives, mentally retarded patients, patients with any co-morbid and patients with broken down roots of impacted mandibular third molar were excluded from this study.

Under local anaesthesia the surgical procedure was performed by giving inferior alveolar nerve and lingual nerve block along with local infiltration. 2\% Xyolcaine with 1:10000 epinephrine (Medicaine; Made in Korea) was used to give local anaesthesia. The operative duration was determined by the time lapse between incision and completion of suturing from low to high i-e. Low 1 (10-20 minutes), 2 (20-40minutes) and high 3 (more than 40 minutes). With the help of blade \#15 (Feather safety razor co. Ltd Japan), the releasing incision was given an envelope flap was raised. Slow hand piece was used to remove buccal cortical bone and extraction of tooth was done by either the use of an elevator or sectioning the tooth and roots where necessary. A sterile normal saline $0.9 \%$ (Searle Ltd. Pakistan) irrigation was used during the tooth sectioning and bone removal. After removal of the tooth, the wound was irrigated and sharp areas were smoothened with the bone file. A 4-0 Vicryl (Johnson \& Johnson; Made in the USA) was used to close the wound.

Duration of the surgery was recorded and during the surgical procedure, trans-operative complications occur like soft tissue injury, injury to the inferior dental canal, adjacent tooth injury, fracture of tooth apex and fracture of the mandible were recorded whenever occurred. Finally, compressive gauze was placed for $30-45$ mins. The patients were given appropriate postoperative instructions. Each patient was given standard antibiotics (Amoxi-clav 625mg BD GSK Pharma Made in Pakistan) and analgesics (Ibuprofen 400mg TDS Abbott Pharma Made in Pakistan) for 5 days. Each patient was re-examined on the $3^{\text {rd }}, 5^{\text {th }}$ and $7^{\text {th }}$ post-operative days. The postoperative complications were recorded on Proforma. Postoperative assessment of pain [using Visual Analogue Scale from zero (no pain) to 10 (worst pain imaginable)], degree of swelling [using criteria published by Amin \& Laskin] ${ }^{21}$ and limited mouth opening [using millimetre ruler (measuring the maximum distance between Upper and lower central incisor)] associated with impacted mandibular third molar is performed. The intra-oral examination was carried out for any other complication such as a dry socket, wound dehiscence or any other soft tissue injury.

\section{RESULTS}

Total ninety two patients were included in this study based on inclusion criteria. The age range of the patient was from 18 years to 35 years. In this study, the mean age was $26.43 \pm 5.20$ with the predilection of female's i-e 53 patients (58\%) than males 39 patients (42\%). Table I.

Surgical removal of impacted lower $3^{\text {rd }}$ molar was classified on angulation and mesioangular was most common impaction 36 patients $(39 \%)$ followed by vertical angulation 28 patients $(31 \%)$, then horizontal 19 patients $(20 \%)$ and least common angulation in this study were distoangular 09 patients $(10 \%)$.

In the present study, preoperative assessment of pain, swelling, and trismus was done. Pain assessment was done on the visual analog scale (VAS). According to gender distribution, in females, the complaint of pain was more (mild 10 patients, moderate 20 patients and severe 23 patients) when compared with males (mild 6 patients, moderate 16 patients, and 17 severe patients). Table II.

Surgical procedure took minimum upto 10 minutes and maximum was more than 40 minutes (Relation of Pre and Post Operative Pain Assessment as shown in Table III). 
Paras Rahim Baloch, Suneel Kumar Punjabi, Shuja Hamid, Priya

Table IV and $\mathrm{V}$ show pre and post operative comparison of mouth opening and swelling

Surgical procedure for removal of impacted tooth was also evaluated according to surgeon's experience as shown in Table VI.

During the postoperative assessment of patients, pain swelling and trismus were assessed. Pain was initially more on $3^{\text {rd }}$ postoperative day which gradually decreased and was mild to moderate on $5^{\text {th }}$ and $7^{\text {th }}$ day postoperatively. The $p$-value of pain calculated by chi-square test was 0.079 . Preoperative maximum mouth opening was $32.29 \pm 4.31$. On $3^{\text {rd }}$ postoperative day, maximum mouth opening was $28.67 \pm 2.85$ which increased on the $7^{\text {th }}$ day with mean $34.94 \pm 3.16$. The p-value was 0.022 calculated using ANOVA. Figure I.

The swelling was found more on the $3^{\text {rd }}$ postoperative day with mean $8.45 \pm 2.50$. On the $5^{\text {th }}$ postoperative day, the swelling was less with mean $6.27 \pm 4.33$ and on $7^{\text {th }}$ day decreased to $3.44 \pm 1.29$. The $p$ - value was 0.045. Figure II.

TABLE I:

DESCRIPTIVE STATISTICS OF AGE $(n=92)$

\begin{tabular}{|l|r|}
\hline \multicolumn{1}{|c|}{ Statistics } & \multicolumn{1}{|c|}{ Age (Year) } \\
\hline Mean \pm SD & $26.43 \pm 5.20$ \\
\hline Median (IQR) & 26 \\
\hline Minimum Age & 18 \\
\hline Maximum Age & 35 \\
\hline
\end{tabular}

TABLE II: PRE-OPERATIVE PAIN ASSESSMENT

\begin{tabular}{|l|r|r|r|}
\hline \multicolumn{3}{|c|}{$\begin{array}{c}\text { Pre-Operative Pain Assessment } \\
\text { (Gender Distribution) }\end{array}$} & n= 92 \\
\hline & \multicolumn{1}{c|}{ Male } & Female & Percentage \\
\hline Mild & 6 & 10 & $17.39 \%$ \\
\hline Moderate & 16 & 20 & $37.73 \%$ \\
\hline Severe & 17 & 23 & $43.47 \%$ \\
\hline
\end{tabular}

TABLE III: RELATION OF PRE AND POST OPERATIVE PAIN ASSESSMENT

\begin{tabular}{|l|r|r|c|}
\hline \multicolumn{3}{|c|}{ Pain Assessment } & n= 92 \\
\hline & $\begin{array}{c}\text { Pre } \\
\text { Operative }\end{array}$ & $\begin{array}{c}\text { Post } \\
\text { Operative }\end{array}$ & P-value \\
\hline Mild & 16 & 25 & \multirow{2}{*}{0} \\
\cline { 1 - 3 } Moderate & 36 & 41 & \multirow{2}{*}{$0.072^{*}$} \\
\cline { 1 - 3 } Severe & 40 & 26 & \\
\hline Total & $\mathbf{9 2}$ & $\mathbf{9 2}$ & \\
\hline
\end{tabular}

TABLE IV: PRE AND POST OPERATIVE COMPARISON OF MOUTH OPENING

\begin{tabular}{|l|r|c|}
\hline \multicolumn{2}{|c|}{ Mouth Opening } & n= 92 \\
\hline & Mean \pm SD & P-value \\
\hline Pre Operative & $32.29 \pm 4.31$ & \multirow{2}{*}{$0.022^{*}$} \\
\cline { 1 - 2 } $3^{\text {rd }}$ Postoperative Day & $28.67 \pm 2.85$ & \multirow{2}{*}{} \\
\cline { 1 - 2 } $5^{\text {th }}$ Postoperative Day & $31.03 \pm 2.44$ & \\
\cline { 1 - 2 } $7^{\text {th }}$ Postoperative Day & $34.94 \pm 3.16$ & \\
\hline
\end{tabular}

*Significant at 0.05 levels using ANOVA

TABLE V: PRE AND POST OPERATIVE COMPARISON OF SWELLING

\begin{tabular}{|l|r|c|}
\hline \multicolumn{2}{|c|}{ Mouth Opening } & n=92 \\
\hline & Mean \pm SD & P-value \\
\hline Pre Operative & $7.83 \pm 1.78$ & \multirow{2}{*}{$0.045^{\star}$} \\
\cline { 1 - 2 } $3^{\text {rd }}$ Postoperative Day & $8.45 \pm 2.50$ & \\
\cline { 1 - 2 } 5th Postoperative Day & $6.27 \pm 4.33$ & \\
\cline { 1 - 2 } $7^{\text {th }}$ Postoperative Day & $3.44 \pm 1.29$ & \\
\hline
\end{tabular}

*Significant at 0.05 levels using ANOVA

TABLE VI: RELATION OF OPERATIVE TIME OF SURGERY WITH SURGEON'S EXPERIENCE $(n=92)$

\begin{tabular}{|c|c|c|c|c|c|}
\hline \multicolumn{6}{|c|}{ Surgeon's Experience } \\
\hline $\begin{array}{l}\text { Time of } \\
\text { Surgery }\end{array}$ & $\begin{array}{c}2 \\
\text { years }\end{array}$ & $\begin{array}{c}3 \\
\text { years }\end{array}$ & $\begin{array}{c}5 \\
\text { years }\end{array}$ & Total & P-value \\
\hline $10-20$ minutes & 3 & 7 & 11 & 18 & \multirow{3}{*}{$0.008^{*}$} \\
\hline 20-40 minutes & 16 & 12 & 7 & 35 & \\
\hline$>40$ minutes & 19 & 15 & 5 & 39 & \\
\hline
\end{tabular}

* Significant at 0.05 levels

\section{FIGURE I: PREOPERATIVE AND POSTOPERATIVE MAXIMUM MOUTH OPENING ASSESSMENT IN MILLIMETRES}

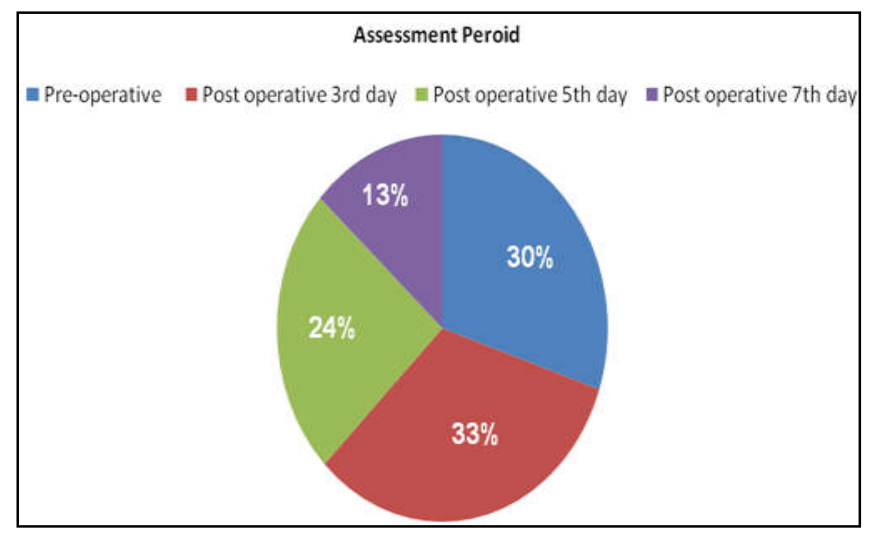




\section{FIGURE II: PREOPERATIVE AND POSTOPERA-} TIVE SWELLING ASSESSMENT IN MILLIMETERS

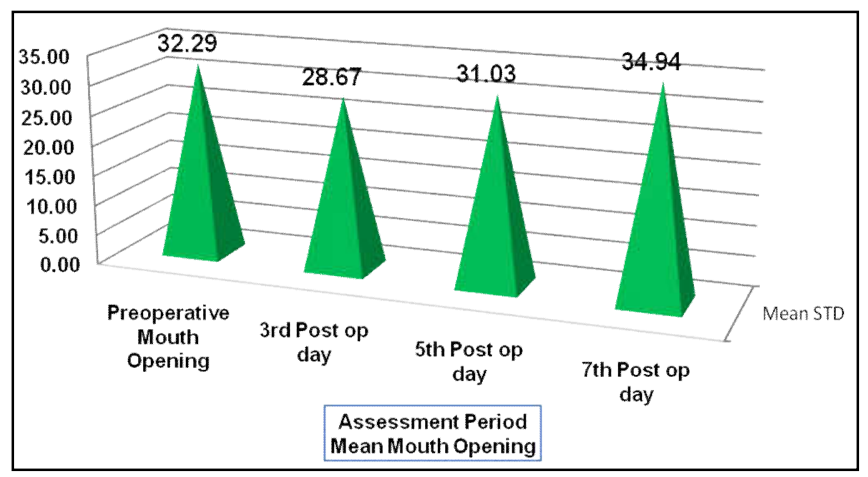

\section{DISCUSSION}

Among the dentoalveolar surgeries impacted teeth were commonly removed as compared to other procedures at oral surgery clinics and hospitals ${ }^{7,8}$.

The mean age of impaction removal in this study was $26.43 \pm 5.20$. The common reasons for presenting third molar impaction removal in this age range was pain, swelling, trismus because of pericoronitis and dental caries. The mean age was $27.2 \pm 6.177$ years, and the $3^{\text {rd }}$ decade is the dominant age group, like other studies $^{6,22}$.

It has been reported that during removal of impaction, patient's age is an important factor because many studies have reported that postoperative complications are increased in older patients. Operative time was found more in elderly patients. The elderly groups was more than twice likely to be the risk of the lengthening of the operational time they had met with the younger age group ${ }^{22}$. Increase in duration of surgery chances of experiencing pain $(\text { VAS }>1)^{23}$.

Some studies showed, impaction of lower $3^{\text {rd }}$ molar was more common in males than females $6,21,24$ however as many studies showed female predilection in patients with impacted lower $3^{\text {rd }}$ molar $^{22,25}$.

After the presenting complaint of patient another reason for surgical removal of impaction were the common pathologies which were caries to distal aspect of $2^{\text {nd }}$ molar followed by periodontal disease $(12.84 \%)^{26}$. Prophylactic removal of asymptomatic impaction were $6.73 \%{ }^{27}$.

Bui $\mathrm{CH} 2003^{7}$. reported complications $2.2 \%$ during the surgical removal of lower $3^{\text {rd }}$ molar and Chiapasco $M$ $2006^{28}$ in his research found the incidence of accidents during operation $1.1 \%$. Khan A $2010^{25}$ investigated the rate of accidents and complications in both the genders. The rate of complications was seen more in female patients $73.91 \%$ when compared with male patients $27.28 \%$.

Complexity of surgical procedures also increases the rate of accidents and complications. Other authors showed increase of postoperative morbidity with increase in duration of surgery ${ }^{29}$.

Pain and swelling after extraction are due to the inflammatory process of oral tissue. The commonest complication was mild pain $(41 \%)$ in a study while the frequency of swelling after third molar impaction removal after 7 days was $40 \%$. These results are supported by Ayaz H $2012^{19}$ and Ali YA $2013^{30}$.

Postoperative pain was less in men compared to the women. Average pain in 24 hours following surgery was $4.01 \pm 0.76$ (range 2-5) based on VAS system. The pain reported among men (3.84) is significantly lower than in women (4.24). After surgery the pain starts as the effects of the local anaesthesia subside and reach peak levels in 6 to 12 hours postoperatively. $37.7 \%$ patients reported mild pain on the third postoperative day and $43.4 \%$ patients had no pain on the seventh postoperative day ${ }^{31}$.

In another study, the absence of trismus after the extraction of partially bony impacted tooth was $49.6 \%$, presence of edema was $62.5 \%$, while these means were $0 \%$ and $37.2 \%$ for trismus after the extraction of mucosal impacted teeth and $13.3 \%$ and $37.5 \%$ for trismus after the extraction of complete bony impacted teeth $^{32}$.

Complications other than pain; swelling and trismus may also be seen. Other postoperative complications include alveolar osteitis, infection, secondary bleeding, wound dehiscence, temporomandibular dysfunction or inferior alveolar nerve paresthesia ${ }^{29}$.

Alveolar osteitis varies widely, from lowest range $(0.5 \%)$ to highest range $(68.4 \%)$ but few studies indicated range between $5-10 \%$. The diagnostic criteria for alveolar osteitis vary from author to author according to their studies ${ }^{29}$.

Damage to the lingual or inferior alveolar nerve (IAN) is one of the delayed and least desired complications of impacted mandibular $3^{\text {rd }}$ molar. Sensory deficits may present as anaesthesia, hypoesthesia, hyperesthesia, or dysesthesia in the distributions of the lingual nerve inferior alveolar nerve, with or without taste disturbance, if the lingual nerve is also affected. After 4-8 weeks of surgical removal of lower $3^{\text {rd }}$ molar, injuries to inferior alveolar nerve (IAN) recovered around $96 \%{ }^{33,34}$.

\section{CONCLUSION}

It was concluded that, the inflammatory complications that can be considered (pain, swelling and trismus) after third molar surgery remain an important factor at the early postoperative periods. The intraoperative and postoperative complication also depends on surgeons experience and duration of procedure which may increase or decrease the sequela of removal impacted teeth. 
Ethical permission: LUMHS ERC approval letter No. LUMHS/REC/575. Dated 27-01-2017.

Conflict of Interest: There was no any conflict of interest.

Funding: There was no any funding agency

\section{REFERENCES}

1. Nazir A, Asif $S$, Akram MA. Surgical removal of trans-alveolar mandibular 2nd premolar impactions by lingual approach. Pak Oral \& Dent J. 2013; 33(1): 35-7.

2. Bouloux G, Steed MB, Perciaccante VJ. Complications of third molar surgery. Oral Maxillofac Surg Clin North Am. 2007; 19(1): 117-28.

3. Hupp J, Tucker M, Ellis E. Contemporary Oral and Maxillofacial Surgery. $6^{\text {th }}$ edition, Mosby Elsevier. 2014.

4. Hassan AH. Pattern of third molar impaction in a Saudi population. Clin Cosmet Investig Dent. 2010; 2: 109-13.

5. Tuteja M, Bahirwani S, Balaji P. An evaluation of third molar eruption for assessment of chronologic age: A panoramic study. J Forensic Dent Sci. 2012; 4(1): 13-8.

6. Shams S, Hassan SG, Punjabi SK, Abdullah S. Molar Caries; Distal surface mandibular second molar caries, existence and association with partially erupted mandibular third molar. Professional Med J. 2017; 24 (7): 1088-92. doi:10.17957/TPMJ /17.3857.

7. Bui $\mathrm{CH}$, Selden EB, Dodson TB. Types, frequencies, and risk factors for complications after third molar extraction. J Oral Maxillofac Surg. 2003; 61(12): 1379-89.

8. Chuang SK, Perrott DH, Susarla SM, Dodson TB. Age as a risk factor for third molar surgery complications. J Oral Maxillofac Surg. 2007; 65 (9): 1685-92.

9. Oliveira LB, Schmidt DB, Assis AP, Gabrielli MAC, Vieira EH, Pereira Filho VA. Review of accidents and complications associated with extraction of third molars. Rev Cir Traumatol Buco-MaxilloFac. 2006; 6: 51-6.

10. Renton T, Smeeton N, McGurk M. Factors predictive of difficulty of mandibular third molar surgery. Br Dent J. 2001; 190(11): 607-10.

11. Olmedo-Gaya MV, Vallecillo-Capilla M, Galvez-Mateos R. Relation of patient and surgical variables to postoperative pain and inflammation in the extraction of third molars. Med Oral. 2002; 7: 360-69.

12. Jerjes W, El-Maaytah M, Swinson B, Banu B, Upile T. D'Sa S, et al. Experience versus complication rate in third molar surgery. Head
Face Med. 2006; 2: 14. doi: 10.1186/1746-160X-2 $-14$

13. Danda AK, Krishna Tatiparthi M, Narayanan V, Siddareddi A. Influence of primary and secondary closure of surgical wound after impacted mandibular third molar removal on postoperative pain and swelling--a comparative and split mouth study. J Oral Maxillofac Surg. 2010; 68(2): 30912. doi: 10.1016/j.joms.2009.04.060.

14. Bello SA, Adeyemo WL, Bamgbose BO, Obi EV, Adeyinka AA. Effect of age, impaction types and operative time on inflammatory tissue reactions following lower third molar surgery. Head Face Med. 2011; 7: 8. doi: 10.1186/1746-160X-7-8.

15. Malkawi Z, Al-Omiri MK, Khraisat A. Risk indicators of postoperative complications following surgical extraction of lower third molars. Med Princ Pract. 2011; 20(4): 321-5. doi: 10.1159/000324550.

16. Akadiri OA, Okoje VN, Arotiba JT. Identification of risk factors for short-term morbidity in third molar surgery. Odontostomatol Trop. 2008; 31(124):5-10.

17. Kim JC, Choi SS, Wang SJ, Kim SG. Minor complications after mandibular third molar surgery: type, incidence, and possible prevention. Oral Surg Oral Med Oral Pathol Oral Radiol Endod. 2006; 102(2): e4-11.

18. Ethunandan $M$, Shanahan $D$, Patel M. latrogenic mandibular fractures following removal of impacted third molars: an analysis of 130 cases. $\mathrm{Br}$ Dent J. 2012; 212(4): 179-84. doi: 10.1038/sj.bdj.2012.135.

19. Ayaz H, Ur-Rehman A, Ur-Din F. Postoperative complications associated with impacted mandibular third molar removal. Pak Oral Dent J. 2012; 32(3): 389-92.

20. Syed KB, Alqahtani FH, Mohammad AH, Abdullah IM, Qahtani HS, Hameed MS. Assessment of Pain, Swelling and Trismus following impacted third molar surgery using injection dexamethasone submucosally: a prospective, randomized, crossover clinical study. J Int Oral Health. 2017; 9(3): 116-21. doi: 10.4103/jioh.jioh_ 65_17.

21. Amin MM, Laskin DM. Prophylactic use of indometacin for prevention of postsurgical complications after removal of impacted third molars. Oral Surg Oral Med Oral Pathol. 1983; 55 (5): 448-51.

22. Benediktsdottir IS, Wenzel A, Petersen JK, Hintze H. Mandibular Third molar removal: Risk indicators for extended operation time, postoperative pain, and complications. Oral Surg Oral Med Oral Patho Oral Radiol Endod. 2004; 97 (4): 438-46. 
23. Baqain ZH, Karaky AA, Sawair F, Khraisat $A$, Duaibis S, Rajab LD. Frequency estimates and risk factors for postoperative morbidity after third molar removal: a prospective cohort study. J Oral Maxillofac Surg. 2008; 66(11): 2276-83. doi: 10.1016/j.joms.2008.06.047.

24. Amanat N, Mirza D, Rizvi KF. Pattern of third molar impaction: frequency and types among patients attending urban teaching hospital of Karachi. Pak Oral Dental J. 2014; 34(1): 34-37.

25. Khan A, Khitab U, Khan MT. Impacted mandibular third molars: pattern of presentation and postoperative complications. Pak Oral Dental J. 2010; 30(2): 35-40.

26. Bataineh AB, Albashaireh ZS, Hazza'a AM. The surgical removal of mandibular third molars: a study in decision making. Quintessence Int. 2002; 33(8): 613-7.

27. Nazir A, Akhtar MU, Ali S. Assessment of Different Patterns of Impacted Mandibular Third Molars and their Associated Pathologies. J Adv Med Dent Sci Res. 2014; 2(2): 14-22.

28. Chiapasco M, Di Cicco L, Marrone G. Side effects and complications associates with third molar surgery. Oral Surg Oral Med Oral Pathol. 2006; 76 (4): 412-20.
29. Azenha MR, Kato RB, Bueno RB, Neto PJ, Ribeiro MC. Accidents and complications associated to third molar surgeries performed by dentistry students. Oral Maxillofac Surg. 2014; 18 (4): 459-64. doi: 10.1007/s10006-013-0439-9.

30. Ali YA, Ibarheem A, Hamad TY. Clinical assessment of position of impacted lower third molars and their indications for extraction. Marietta Daily J. 2013; 10(2): 210-5.

31. Farshid A, Mohiti AK, Ghasemzadeh O. Prevalence and Risk Factors for Complications of Mandibular Third Molar Surgery. Am J Oral Maxillofac Surg. 2014; 2: 43-52.

32. Atalay B, Guler N, Cabbar F, Sencift K. Determination of incidence of complications and life quality after mandibular impacted third molar surgery. J Istanbul Uni. 2014; 48 (1): 31-46.

33. Deliverska ED, Petkova M. Complications after extraction of impacted third molar- Literature Review. J IMAB. 2016; 22(2): 1202-1211. doi:10.5272/ jimab.2016223. 1202.

34. Panjabi SK, Khoso NA, Butt Am, Channar KA. Third Molar Impaction: Evalution of the symptoms and pattern of mandibular third molar teeth. J Liaquat Uni Med Health Sci. 2013;12(1): 26-29.

\begin{tabular}{|l|}
\multicolumn{1}{c|}{ AUTHOR AFFILIATION: } \\
Dr. Paras Rahim Baloch \\
Senior Lecturer \\
Department of Oral Medicine \\
Dow University of Health Sciences, Karachi, Sindh-Pakistan. \\
Dr. Suneel Kumar Punjabi (Corresponding Author) \\
Associate Professor \\
Department of Oral \& Maxillofacial Surgery \\
Liaquat University of Medical \& Health Sciences \\
(LUMHS), Jamshoro, Sindh-Pakistan. \\
Email: drsunilpanjabi@yahoo.com \\
Dr. Shuja Hamid \\
PG Resident \\
Department of Oral \& Maxillofacial Surgery \\
LUMHS, Jamshoro, Sindh-Pakistan. \\
Dr. Priya \\
Lecturer \\
Department of Community Dentistry \\
Bibi Aseefa Dental College, Larkana, Sindh-Pakistan. \\
\hline
\end{tabular}

